\title{
Subtropical Australian juvenile fish eat meiofauna: experiments with winter whiting Sillago maculata and observations on other species*
}

\author{
Bruce C. Coull ${ }^{1, * *}$, Jack G. Greenwood ${ }^{2}$, Donald R. Fielder ${ }^{2}$, Brent A. Coull ${ }^{3}$ \\ ${ }^{1}$ Belle W. Baruch Institute for Marine Biology \& Coastal Research and Department of Biological Sciences, \\ University of South Carolina, Columbia, South Carolina 29208, USA \\ ${ }^{2}$ Department of Zoology, University of Queensland, Brisbane, Queensland 4072, Australia \\ ${ }^{3}$ Department of Statistics, University of Florida, Gainesville, Florida 32611, USA
}

\begin{abstract}
Meiofauna are known to be trophically integrated into estuarine food webs in temperate regions primarily as food for bottom-feeding juvenile fishes. In subtropical/tropical mangrovedominated estuaries there were few data indicating juvenile fish utilized meiofauna for food. After determining several fishes that ate meiofauna in southeastern Queensland, Australia, juvenile winter whiting Sillago maculata were allowed to feed on natural mud-dwelling meiofaunal communities in microcosms. Six juvenile whiting ( 21 to $38 \mathrm{~mm}$ ) significantly reduced both the nematode and copepod populations in the feeding microcosms and ate a mean of 177 nematodes and 65 copepods fish ${ }^{-1} \mathrm{~h}^{-1}$ This feeding rate, if continued 4 times a day, is sufficient to provide an adequate daily ration for the whiting (based on estimates from similarly feeding North American juvenile fish). Of the available copepods the whiting ate significantly more Brianola sp., Canuellidae sp. and Ectinosoma sp. than would have been expected by chance. They did not select Stenhelia (D.) sp., probably because it burrowed beyond the bite depth of the whiting. Whiting are an economically important fish in the IndoPacific and they require meiofauna in their diet during the juvenile stages. They obtain this meiofauna from mangrove-derived detrital muds; in an aquaculture setting they would probably need to be fed meiofauna.
\end{abstract}

KEY WORDS: Meiofauna - Fish feeding - Copepods - Selectivity · Mud - Mangroves - Queensland Australia

\section{INTRODUCTION}

The role of meiofauna (defined here as benthic metazoans that pass a $500 \mu \mathrm{m}$ sieve but are retained on meshes of less than $100 \mu \mathrm{m}$ ) as food for higher trophic levels is little known in Australia. Many examples from the temperate northern hemisphere (see Coull 1990), one from New Zealand (Hicks 1984) and one from temperate Victoria, Australia (Shaw \& Jenkins 1992), demonstrate the integration of meiobenthos into the food web of the demersal/natant

- Contribution no. 1035 from the Belle W. Baruch Institute for Marine Biology \& Coastal Research, University of South Carolina

•.E-mail: bccoull@sc.edu fauna. Such integration appears universal in temperate waters of both the northern and southern hemispheres, but little is known of the interaction in the subtropics. Only Alheit \& Scheibel (1982) from Bermuda and Warburton \& Blaber (1992) from Queensland, Australia, provide data on meiofauna in the guts of subtropical fish.

Many bottom-feeding juvenile fish pass through an obligatory meiobenthos (particularly copepod) feeding stage (de Morais \& Bodiou 1984). Since 1979 there have been 60 papers published documenting meiofauna as food for higher trophic levels (Coull 1990, unpubl.). In $83 \%$ of these papers juvenile fish are reported as the predators ( 31 different species) and $88 \%$ report that benthic copepods are the predominant prey items in the guts of the fish (Gee 1989, 
Coull 1990). Copepod dominance may be real (e.g. Nelson \& Coull 1989) or an artifact of non-chitinous meiofauna being digested rapidly and thus not being visually present in the fish guts (Scholz et al. 1991, Feller \& Coull 1995). Whatever the reasons it is very clear that meiobenthic copepods are an important dietary component of many juvenile fishes from around the world.

In detritus-based Spartina alterniflora ecosystems in the southeastern United States, meiofauna are fully integrated into the diet of juvenile fish (see Coull 1990 and Feller \& Coull 1995 for synopses) and one might therefore expect them to be so integrated in detritusbased mangrove systems of the subtropics. However, there have been no quantitative studies of the role of meiofauna as food for higher trophic levels in mangrove ecosystems (see Alongi \& Sasekumar 1992). Nematodes have been reported in the guts of prawns and small fish in Indian mangroves (Krishnamurthy et al. 1984). Moreton Bay, southeastern Queensland, where the present study was conducted, is, in many ways, the subtropical mangrove equivalent of southeastern U.S. salt marsh ecosystems. Both are highly productive detritus-based ecosystems (mangrove vs Spartina) with copious quantities of rich detrital mud where most juvenile meiofaunal-feeding fish prefer to feed (Smith \& Coull 1987, Coull 1988, Shaw \& Jenkins 1992), both are shallow estuarine systems that serve as major nursery grounds for juvenile fish, both are used heavily for recreational fishing, and both are under threat of destruction from urban/industrial development.

The overall objective of the present study was to determine the role of meiofauna in the diet of Moreton Bay juvenile fish and compare this role to that known from southeastern U.S. salt marsh ecosystems. Specifically, we determined juveniles of several fish species that ate meiofauna and selected one (the winter whiting or trumpeter sillago Sillago maculata Quoy \& Gaimard) for experimental feeding trials with meiofauna. Whiting (several species) are important recreational and commercial fishes in Australia $6082 \mathrm{t}$ reported landed in 1990 (McKay 1992), and S. maculata is a major species in Queensland (Quinn 1992). There were $22718 \mathrm{t}$ of sillaginid fishes reported to be commercially landed in the IndoPacific region in 1990 (McKay 1992), but this is probably a gross underestimate because in many areas they are taken by small-scale fishermen who do not record their catches (McKay 1992). They are also important in estuarine aquaculture in India, Japan and Taiwan, with research under way in Australia (Mckay 1992), thus determining their natural food requirements is imperative. In our experiments juvenile whiting were allowed to feed on natural meio- faunal communities in microcosms to determine how many, and what kinds of, meiofauna were eaten.

\section{METHODS}

Sampling and experimental procedure. Juvenile fish were collected by seine ( $2 \mathrm{~mm}$ mesh) and dip net ( $1 \mathrm{~mm}$ mesh) from several areas in Moreton Bay. Various fish so collected, and preserved fish previously collected by researchers at the University of Queensland, were dissected and their gut contents examined. Every winter whiting Sillago maculata less than $43 \mathrm{~mm}$ standard length (SL) examined had meiofauna (especially benthic harpacticoid copepods) in the stomach (foregut) and intestine (hindgut). These whiting were very common, obviously feeding on meiofauna in nature, and the copepods in their guts belonged to genera found in muddy intertidal Moreton Bay substrates (Hicks \& Coull 1983). Thus juvenile winter whiting and muddy substrates were selected for experimentation.

Whiting for the experimental trials were collected from Wellington Point, Redlands Shire, Queensland $\left(27^{\circ} 27.8^{\prime} \mathrm{S}, 153^{\circ} 14.4^{\prime} \mathrm{E}\right)$. Fish for the experiments were then transported to the Fisheries Laboratory, CSIRO, Cleveland, Queensland, and held in the running seawater aquaculture laboratory. The fish were collected the day before the experimental trials and starved for $24 \mathrm{~h}$ prior to use.

Whole sediment experiments (sensu Smith \& Coull 1987, Service et al. 1992) were conducted in microcosms made of PVC pipes $(23.5 \mathrm{~cm}$ inner diameter $x$ $22.5 \mathrm{~cm}$ height) with two $5.5 \mathrm{~cm}$ diameter windows cut $11 \mathrm{~cm}$ up from the base. These microcosms used as cores were sunk $6 \mathrm{~cm}$ deep in very soft mangrovedetrital muds adjacent to the boat ramp of the CSIRO laboratory in Cleveland $\left(27^{\circ} 31^{\prime} \mathrm{S}, 153^{\circ} 17^{\prime} \mathrm{E}\right)$, sealed at the bottom with a $29 \times 29 \mathrm{~cm}$ metal sheet and transported to an empty laboratory seawater table within $20 \mathrm{~min}$. The microcosms' (with the $6 \mathrm{~cm}$ of mud) windows were covered with $77 \mu \mathrm{m}$ mesh to prevent meiofauna/fish escaping, and coarsely filtered running seawater was introduced slowly into the seawater table. The final water level was maintained at the window openings and the microcosms were allowed to equilibrate overnight. The entire experiment was conducted twice. In the first replicate (19 August 1994) there were 8 microcosms, 4 with fish and 4 without fish. In the second replicate (5 September 1994), there were 6 microcosms, 4 had fish, 2 did not. Immediately before experimentation three $2.0 \mathrm{~cm}$ inner diameter cores $(4 \mathrm{~cm}$ deep to include the redox layer) were taken from each microcosm to estimate initial (before fish addition) meiofaunal abundance in the microcosm. The core holes were filled 
with cured silicone plugs. Into 4 randomly chosen microcosms, six 21 to $38 \mathrm{~mm}$ starved whiting were added and allowed to feed for $6 \mathrm{~h}$. After $6 \mathrm{~h}$ of fish feeding, another set of three $2.0 \mathrm{~cm}$ diameter cores were taken in both the fish and no-fish microcosms. All initial and final cores were fixed in $10 \%$ formalin/Rose Bengal. The fish were removed immediately and fixed after the final cores had been taken. Meiofauna from the cores and from the fish guts were enumerated to major taxon and copepod species.

Statistical analyses. Nematodes and copepods comprised $98.7 \%$ of the fauna and thus were the taxa analyzed. To control for differences in initial abundances between microcosms when examining the effects of the fish, an analysis of covariance (ANCOVA) was conducted using the final abundance as the response, the initial abundance as the covariate, and presence of fish as the treatment. No evidence of heterogeneity of slopes was found (copepods: $p=0.8230$; nematodes: $\mathrm{p}=0.5018$ ). In addition, initial abundances were not significantly different in the microcosms containing fish from those not containing fish (copepods: $\mathrm{p}=$ 0.3948 ; nematodes: $p=0.3462$ ). Thus, no evidence of assumption violations was found for the ANCOVA analysis. Least-square mean final abundances were examined to determine which treatment (fish or no fish) had lower abundance values for the average initial abundance (the covariate). A paired t-test was used to detect differences between initial abundances and final abundances for those microcosms not containing fish.

To determine if 1 or more copepod species was preferentially selected by the preying fish, we estimated the natural $\log (L)$ of the odds ratio $(O)$, i.e. $O=$ $p_{1}\left(1-p_{2}\right) / p_{2}\left(1-p_{1}\right)$, where $p_{1}$ is the proportion of a prey taxon in the diet of fish and $p_{2}$ is the proportion of a prey taxon in the environment where the fish had fed. Following Gabriel (1979), 95\% confidence intervals on $L$ were calculated, in effect testing the null hypothesis of no selectivity for each copepod species (i.e. the preying fish did not select a particular species). The sign ( \pm ) of the statistic $L$ and the confidence limits indicates a positive or negative selection, respectively. Additionally, the further a confidence interval is from zero, the more selective the fish are toward a particular species. In order to make these confidence intervals more interpretable, the antilog of the confidence limits of $L$ was taken to provide $95 \%$ confidence limits on $O$ (Agresti 1990). For example, a confidence interval $(5,10)$ on $O$ for a particular species would estimate the odds of finding a copepod of that species in the fish gut to be 5 to 10 times greater than the odds of finding that species in the feeding arena. Statistical analyses were conducted using SAS (1985) and SPLUS (Becker et al. 1988).

\section{RESULTS}

From the field-collected fish, fish in other investigators' collections and 1 fish known from the literature, 7 species of Queensland fish (Table 1) were recorded as having benthic copepods as an important component of their gut contents (Table 1). Winter whiting and the goby Favonigobius exquisitus (Whitley) had almost exclusively harpacticoid copepods in their guts (Table 1).

Water temperature and salinity in the first whiting feeding experiment were $19.7^{\circ} \mathrm{C}$ and $35 \%$, in the second replicate $21^{\circ} \mathrm{C}$ and $35 \%$ respectively. The paired $t$ test indicated no significant difference between initial and final nematode and copepod abundances for those microcosms without fish (copepods: $p=0.3597$; nematodes: $p=0.2044$ ) (Fig. 1). The ANCOVA indicated a significant difference between the final abundances for the microcosms containing fish and those not containing fish for a constant value of initial abundance (copepods: $p=0.0001$; nematodes: $p=0.0001$ ). The final abundance least-square means (lsmean) for fish and no-fish microcosms demonstrated both taxa were significantly reduced in microcosms containing fish (copepod lsmean: fish $=42.68$, no fish $=96.85$; nematode lsmean: $\mathrm{fish}=111.63$, no fish $=258.66$ ). Mean initial nematode abundance was $269.8 \pm 14.6$ (SE) per $10 \mathrm{~cm}^{2}$ and copepods averaged $113.3 \pm 6.1$ per $10 \mathrm{~cm}^{2}$ in the initial samples. Fig. 1 gives a summary of the initial means and the least-square means for the final meiofaunal abundances in the fish and no-fish microcosms.

When the difference in meiofauna abundance (final no-fish value minus final fish value, i.e. the calculated number of meiofauna removed) was converted to the whole aquarium $\left(433.7 \mathrm{~cm}^{2}\right)$ the fish removed a mean of 6380 nematodes and 2344 copepods over the $6 \mathrm{~h}$ feeding period. This equates to 177 nematodes and 65 copepods fish ${ }^{-1} \mathrm{~h}^{-1}$. Because not all fish fed this is a conservative estimate of individual consumption.

Of 48 fish used in the experiments, 40 were examined $(8$ fish escaped our collection at the end of the experiment) and 26 of the 40 had meiofauna in their guts (Table 2). The gut contents (foregut and hindgut) of the whiting allowed to feed were overwhelmingly dominated by copepods, even though nematodes were the dominant taxon in the sediments and were significantly reduced by the fish feeding (Fig. 1). Copepods comprised $96.5 \%$ (range 0 to 313 copepods fish $^{-1}$ ) of the prey in the foregut and were the only prey in the hindgut. Enumeration and identification of the hindgut copepods was impossible because they were primarily in pieces. Nematodes were rare in both portions of the gut com- 
Table 1. Field-collected Queensland juvenile fish with meiofauna in guts

\begin{tabular}{|c|c|c|c|c|c|c|}
\hline Species & $\begin{array}{l}\text { Common } \\
\text { name }\end{array}$ & $\begin{array}{l}\text { No } \\
\text { examined }\end{array}$ & $\begin{array}{l}\text { No. with } \\
\text { meiofauna }\end{array}$ & $\begin{array}{c}\text { Size of fish } \\
\text { examined }(\mathrm{mm})\end{array}$ & $\begin{array}{l}\text { Dominant } \\
\text { prey }\end{array}$ & $\begin{array}{l}\text { Mean } \% \text { dominan } \\
\text { prey by number }\end{array}$ \\
\hline \multicolumn{7}{|l|}{ Sillaginidae } \\
\hline $\begin{array}{l}\text { Sillago maculata } \\
\text { Quoy \& Gaimard }\end{array}$ & Winter whiting & 43 & 43 & $15-43$ & $\begin{array}{l}\text { Harpacticoid } \\
\text { copepods }\end{array}$ & $>80$ \\
\hline S. cillata Cuvier & Sand whiting & 7 & 4 & $21-38$ & Harpacticoids & 47 \\
\hline \multicolumn{7}{|l|}{ Gobiidae } \\
\hline $\begin{array}{l}\text { Favongobius } \\
\text { exquistus Whitley }\end{array}$ & Goby & 16 & 15 & $16-31$ & Harpacticoids & $>80$ \\
\hline Amoya sp. & Goby & 6 & 4 & $17-27$ & $\begin{array}{l}\text { Harpacticoids/ } \\
\text { foraminiferans }\end{array}$ & $50 / 40$ \\
\hline $\begin{array}{l}\text { Valenciennia } \\
\text { longipinnis } \\
\text { (Lay \& Bennett) }^{a}\end{array}$ & Goby & $?$ & $?$ & $?$ & Harpacticoids & 56 \\
\hline \multicolumn{7}{|l|}{ Theraponidae } \\
\hline $\begin{array}{l}\text { Pelates quadra- } \\
\text { lineatus (Bloch) }\end{array}$ & Trumpeter & 9 & 9 & $19-40$ & Harpacticoids & $41^{b}$ \\
\hline \multicolumn{7}{|l|}{ Leiognathidae } \\
\hline $\begin{array}{l}\text { Leiognathus } \\
\text { moretoniensis } \\
\text { (Ogilby) }\end{array}$ & $\begin{array}{l}\text { Black banded } \\
\text { pony fish }\end{array}$ & 1 & 1 & 45 & Harpacticoids & $65^{\mathrm{b}}$ \\
\hline $\begin{array}{l}\text { L. splendens } \\
\text { (Cuvier) }^{c}\end{array}$ & Pony fish & 1 & 1 & 65 & $\begin{array}{l}\text { Harpacticoid } \\
\text { Longipedia sp. }\end{array}$ & $>80$ \\
\hline \multicolumn{7}{|c|}{$\begin{array}{l}\text { All information from St. John et al. (1989). Fish not examined by present authors } \\
\text { b Warburton \& Blaber (1992) also report harpacticoid copepods as a dominant prey item } \\
\text { ' Specimen from Gulf of Carpentaria, Queensland. From Mr Jonathan Staunton-Smith (University of Queensland). } \\
\text { Copepods identified by B. C. Coull }\end{array}$} \\
\hline
\end{tabular}

prising only $3.4 \%$ (maximum of 11 nematodes in 1 fish) in the foregut (Table 2); no nematodes were observed in the hindgut. The 26 fish had a total of 2423 copepods in the foregut.

Twelve species of benthic copepods were identified from the initial sediment samples. Six species comprised $84 \%$ of all the copepods (Table 3 ). Of the 40 fish examined, the gut contents contained the same 6 species, but in different proportions (Table 3 ). In the log odd ratio se- lectivity analysis none of the $95 \%$ confidence intervals contained zero, i.e. the null hypothesis of no selectivity is rejected at the $0.05 \alpha$ level for all species. Canuellidae sp., Brianola sp. and Ectinosoma sp. were positively selected by the fish while Stenhelia (D.) sp., Halicyclops sp., Coullana sp., and the other species were negatively selected, i.e. not taken in proportion to their abundance in the microcosms (Table 3). All the copepod species are undescribed and will be described elsewhere.
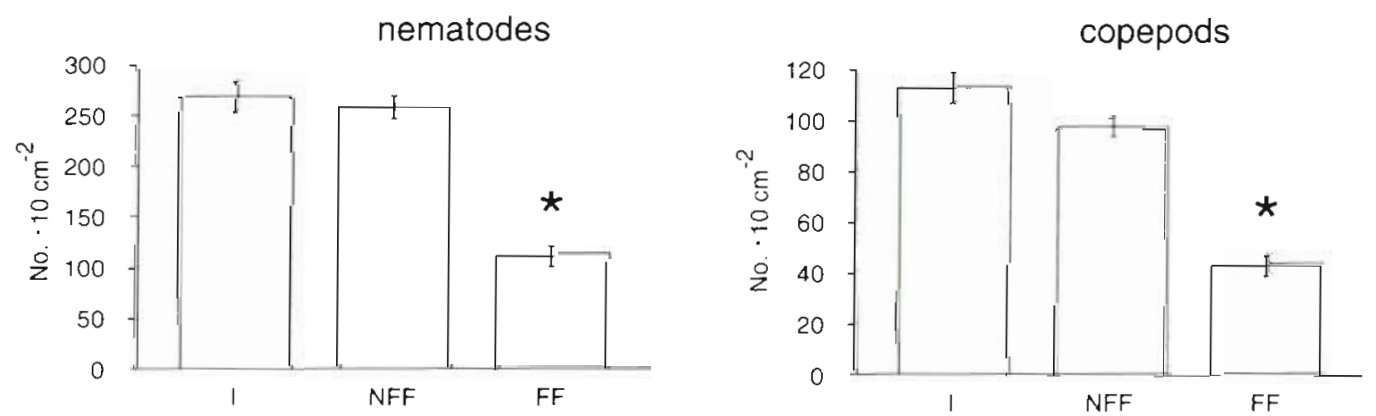

Fig. 1. Mean abundance ( \pm SE) of nematodes and copepods initially (I), and after the $6 \mathrm{~h}$ in treatments with fish (FF) and no fish (NFF). * Significant abundance difference at $p<0.05$ 
Table 2. Abundance of meiofauna taxa in the foreguts of 26 fish that fed in the microcosm experiments. Y; yes; $N$ : no

\begin{tabular}{|c|c|c|c|c|c|}
\hline Fish & $\begin{array}{c}\text { Fish } \\
\text { size }(\mathrm{mm})\end{array}$ & $\begin{array}{l}\text { Cope- } \\
\text { pods }\end{array}$ & $\begin{array}{c}\text { Nema- } \\
\text { todes }\end{array}$ & $\begin{array}{l}\text { Other } \\
\text { taxa }\end{array}$ & $\begin{array}{l}\text { Carcasses } \\
\text { in hindgut }\end{array}$ \\
\hline 1 & 23 & 161 & 2 & 1 & $Y$ \\
\hline 2 & 34 & 103 & 4 & 0 & $Y$ \\
\hline 3 & 24 & 39 & 2 & 1 & $Y$ \\
\hline 4 & 30 & 146 & 3 & 0 & $Y$ \\
\hline 5 & 29 & 173 & 2 & 0 & $Y$ \\
\hline 6 & 28 & 7 & 0 & 0 & $N$ \\
\hline 7 & 24 & 227 & 5 & 4 & $\mathrm{Y}$ \\
\hline 8 & 38 & 153 & 3 & 1 & $Y$ \\
\hline 9 & 32 & 54 & 1 & 1 & $Y$ \\
\hline 10 & 28 & 74 & 1 & 1 & $Y$ \\
\hline 11 & 36 & 28 & 2 & 1 & $Y$ \\
\hline 12 & 31 & 313 & 11 & 2 & $Y$ \\
\hline 13 & 32 & 76 & 3 & 1 & $Y$ \\
\hline 14 & 23 & 56 & 0 & 0 & $Y$ \\
\hline 15 & 27 & 27 & 0 & 1 & $Y$ \\
\hline 16 & 25 & 29 & 1 & 1 & $Y$ \\
\hline 17 & 24 & 30 & 1 & 1 & $\mathrm{Y}$ \\
\hline 18 & 31 & 24 & 2 & 0 & Y \\
\hline 19 & 36 & 221 & 6 & 1 & $Y$ \\
\hline 20 & 24 & 72 & 2 & 0 & $Y$ \\
\hline 21 & 28 & 11 & 0 & 0 & $\mathrm{~N}$ \\
\hline 22 & 31 & 163 & 6 & 2 & $Y$ \\
\hline 23 & 29 & 42 & 1 & 2 & $\mathrm{Y}$ \\
\hline 24 & 31 & 19 & 2 & 0 & $\mathrm{~N}$ \\
\hline 25 & 26 & 69 & 0 & 2 & $\mathrm{Y}$ \\
\hline 26 & 37 & 101 & 3 & 1 & $Y$ \\
\hline
\end{tabular}

\section{DISCUSSION}

The 7 field-collected fish species with meiofauna in their guts (Table 1) were all relatively small fish. The $65 \mathrm{~mm}$ pony fish Leiognathus splendens was a surprise; rarely do fish over $40 \mathrm{~mm}$ have meiofauna in their guts. However, pony fish have a protrusible buccal apparatus that tapers to a small opening and thus, while larger than the typical fish that eats meiofauna, the mouth gape is approximately the same size. We report on winter whiting 15 to $43 \mathrm{~mm}$ (Table 1), but we dissected several specimens between 43 and $80 \mathrm{~mm}$ and found no meiofauna in any whiting in this size range. Once the whiting reach $43 \mathrm{~mm}$, their diet consists of polychaetes, amphipods and other larger crustaceans. This is consistent with other meiofaunal feeding fishes that undergo an ontogenetic shift to macrofaunal sized prey at some particular size. With whiting it appears to be around $40 \mathrm{~mm}$; with flatfishes it occurs at a much smaller size (Hicks 1984, Gee 1989, Shaw \& Jenkins 1992).

Six 21 to $38 \mathrm{~mm}$ juvenile whiting feeding in mangrove-derived detrital mud reduced nematode abundance by $54 \%$ and copepod abundance by $56 \%$ over the $6 \mathrm{~h}$ feeding period. Most of the fish from the microcosms had meiofauna in their guts (Table 2). Clearly there was feeding on the meiofauna (Fig. 1) and, like juvenile spot from the southeastern U.S. the whiting significantly reduced the abundance of nematodes and copepods in the microcosms. Smith \& Coull (1987) found that 30 similarly sized juvenile spot feeding in natural mud reduced nematodes by $29 \%$ and copepods by $52 \%$ over $12 \mathrm{~h}$. In only $6 \mathrm{~h}, 6$ whiting reduced more than twice the amount of nematodes that the spot had, and about an equal amount of copepods. Removal of 177 nematodes and 65 copepods $\mathrm{h}^{-1}$ whiting $^{-1}$ is a substantial removal rate, matching the daily ration calculations for juvenile spot (Feller \& Coull 1995). Based on foregut content only there were 2423 copepods in the guts of 26 fish allowed to feed for 6 h (Table 2), while the same 26 fish accounted for the removal of 10140 copepods in the $6 \mathrm{~h}$ (26 fish $\times 65$ copepods $h^{-1} \times 6 h$ ). If there was the same amount of copepods in the hindgut (they could not be enumerated because they were in pieces) as in the foregut, then approximately one-half of the missing copepods are accounted for in the fish guts. Perhaps the others were eaten early during the feeding period and passed. If juvenile whiting (like 
juvenile spot) feed up to 4 times a day (sensu Feller \& Coull 1995) they should be able to sustain their necessary growth from the number of copepods removed.

A most surprising result of the major taxon analyses was the absence of nematodes in the guts of the fish, even though the whiting removed $54 \%$ of all the nematodes. Where did the nematodes go? Most likely the nematodes were digested with no visual remains. In juvenile spot, nematodes can only be observed visually for $2 \frac{1}{2} \mathrm{~h}$ after ingestion; copepods remain visible for the entire gut clearance time, up to $8 \mathrm{~h}$ (Scholz et al. 1991). We suspect this to be similarly true for the juvenile whiting studied here. They feed similarly to spot, taking small bites of the sediment surface and somehow extracting the meiofauna - we don't know exactly how spot extract the meiofauna either, although it has been suggested that the gill rakers are involved (Yetman 1979). Gut clearance times are probably also similar for these similarly feeding and sized fish. Spot gut volume and fullness decreased to constant levels in $4 \mathrm{~h}$ (Feller \& Coull 1995). If nematodes are also similarly digested in about $2 \mathrm{~h}$ in the whiting, and gut clearance is 4 to $6 \mathrm{~h}$, the whiting most likely fed on nematodes in the first $4 \mathrm{~h}$ of our experiment and, just like spot, ingested nematodes were digested before we fixed the fish for observation. Alternatively, the nematodes may not have been eaten, but burrowed deeper into the sediment in response to the feeding fish (Fitzhugh \& Fleeger 1985) and were therefore not collected by our sampling. This is unlikely since we took our samples to include the redox layer. While some nematodes have the ability to withstand anoxia for long periods of time (Heip et al. 1985), most marine free-living nematodes inhabit oxic sediments (Heip et al. 1985). Thus there was no vertical escape route for most of the nematodes and they therefore must have been eaten.

Retrospectively, we probably let our fish feed too long. Beside the nematode digestion problem mentioned above, we saw many benthic copepod exoskeletons in the hindgut (evidence of early feeding, and digestion). The absence of prey in 14 of the 40 fish (Table 2) may have been the result of fish that fed early and cleared their guts. We also suspect the meiofauna might have been greatly reduced in the first few hours and thus prey density would have been below the threshold level necessary for continued or adequate fish feeding. We would recommend that similar future experiments be conducted for no longer than $4 \mathrm{~h}$.

The confidence interval for the odds ratio (selectivity) for Brianola sp. provides the strongest evidence of positive selection (Table 3 ). The odds of finding Brianola sp. in a fish gut was estimated to be 3.5 to 5.5 times the odds of finding Brianola sp. in the microcosms. Clearly, Brianolasp. was the favorite food of the fish. Brianola sp. is a large harpacticoid $(0.75 \mathrm{~mm})$ and a surface dweller. The other species positively taken by the whiting, Canuellidae sp. and Ectinosoma sp., also occupy the surface flocculent layer.

Most strikingly absent from the fish guts was Stenhelia $(D$.$) sp., which comprised 14.4 \%$ of the available fauna but only $1.0 \%$ of the copepods in the fish foregut. The $95 \%$ confidence interval on the odds ratio for Stenhelia (D.) sp. estimated the odds of finding a Stenhelia (D.) sp. in the microcosms to be approximately 10 to 20 times the odds of finding a Stenhelia (D.) sp. in the fish gut (Table 3). That juvenile whiting did not eat Stenhelia (D.) sp. is fully consistent with previous studies of juvenile fish feeding in muddy copepod assemblages with genera similar to those encountered here. Feller et al. (1990) found few Stenhelia $(D$.) bifidia in the guts of juvenile spot, even though it was overwhelmingly the dominant species where the fish were feeding and Service et al. (1992) also found the species was not taken in microcosm studies with juvenile spot. Stenhelia species in intertidal habitats tend to burrow relatively deep $(0.5$ to $1.0 \mathrm{~cm}$ ), and in the case of spot, as probably also with the whiting here, the fish do not bite the sediment deep enough to take members of this genus. Clearly the fish (spot and whiting) feed in the very surficial sediments because both of them have copepod genera in their guts characteristic of the upper few mm of sediment.

Juvenile winter whiting feed heavily in intertidal, detritally derived mangrove mud in Queensland. These sediments have an abundance of meiofauna and obviously provide most of the nutrition for these fish. They clearly select surface-dwelling harpacticoid copepods as their primary prey. Sillaginid fishes are an important economic resource in the Indo-Pacific region (McKay 1992) and as more and more of their juvenile feeding habitat is removed for development or impacted by other anthropogenic effects, one might expect decreased fisheries yields. Perhaps the increased use of sillaginids in aquaculture (McKay 1992) would counter any loss from the capture fisheries. In any case meiofauna are important members of the diet for these fishes in their juvenile stages and either the fishes need to have access to muddy substrates to feed or have meiofauna included in the diet of cultured fishes.

Acknowledgements. This research was conducted while the senior author was a visiting Professor in the Department of Zoology, University of Queensland. Grateful thanks to the Department of Zoology, University of Queensland for providing facilities and supplies, and the Division of Fisheries, CSIRO, Cleveland, Queensland for use of their running seawater aquaculture laboratory to conduct the feeding expenments. Michelle Hollaway and Doug Lewinski (Univ. Queensland) assisted with the sampling/experimentation. We thank R. J. Mckay, Curator of Fishes, Queensland Museum, for identifying our predator as Sulago maculata, Dr H. K. Larson, 
Curator of Fisheries, Museums and Art Galleries of the Northern Territory, Darwin, Northern Territory, for providing taxonomic advice on the gobies examined, Frank Fiers, Institut Royal des Sciences Naturelles de Belgique, for identifying the harpacticoid copepods of the family Canuellidae and $J$ Staunton-Smith, B. Crowley and T Pham (Univ. Queensland) for allowing us to examine guts of fish they had collected. This research was supported by the U.S. National Science Foundation, grant OCE-9313997 to B.C.C.

\section{LITERATURE CITED}

Agresti A (1990) Categorical data analysis. Wiley Series in Probability and Mathematical Statistics. Wiley-Interscience, New York

Alheit J, Scheibel W (1982) Benthic harpacticoids as a food source for fish. Mar Biol 70:141-147

Alongi DM, Sasekumar A (1992) Benthic communities. In Robertson AI Alongi DM (eds) Tropical mangrove ecosystems. Coastal and Estuarine Studies 41, American Geophysical Union, Washington, DC, p 137-171

Becker RA, Chambers JM, Wilks AR (1988) The new S language. A programming environment for data analysis and graphics. Wadsworth \& Brooks/Cole Advanced Books \& Software, Pacific Grove, CA

Coull BC (1988) Ecology of the marine meiofauna. In: Higgins RP, Thiel H (eds) An introduction to the study of meiofauna. Smithsonian Institution Press, Washington, DC, p 18-38

Coull BC (1990) Are member of the meiofauna food for higher trophic levels? Trans Am Microsc Soc 109:233-246

deMorais LT, Bodiou JY (1984) Predation on meiofauna by juvenile fish in a western Mediterranean flatfish nursery ground. Mar Biol 82:209-215

Feller RJ, Coull BC, Hentschel BT (1990) Meiobenthic copepods: tracers of where juvenile Leiostomus xanthurus (Pisces) feed? Can J Fish Aquat Sci 47:1913-1919

Feller RJ, Coull BC (1995) Non-selective ingestion of meiobenthos and the daily ration of juvenile spot, Leiostomus xanthurus (Pisces). Vie Milieu 45:49-59

Fitzhugh GR, Fleeger JW (1985) Goby (Pisces: Gobiidae) interactions with meiofauna and small macrofauna. Bull mar Sci 36:436-444

Gabriel WL (1979) Statistics of selectivity. In: Lipovsky SJ, Simenstad CA (eds) Gutshop 78, Fish Food Habits Studies, Proceedings of the Second Pacific Northwest Technical Workshop. Washington Sea Grant Publication, University of Washington, Seattle, p 62-66

Gee JM (1989) An ecological and economic review of meiofauna as food for fish. Zool J Linn Soc 96:243-261

This article was presented by K.R. Tenore (Senior Editorial Advisor), Solomons, Maryland, USA
Heip C, Vincx M, Vranken G (1985) The ecology of marine nematodes. Oceanog mar Biol A Rev 23:399-489

Hicks GRF (1984) Spatio-temporal dynamics of a meiobenthic copepod and the impact of predation-disturbance. J exp mar Biol Ecol 81:47-72

Hicks GRF, Coull BC (1983) The ecology of marine meiobenthic harpacticoid copepods. Oceanogr mar Biol A Rev $21: 67-195$

Krishnamurthy MA, Sultan Ali MA, Prince Jeyaseelan MJ (1984) Structure and dynamics of the aquatic food web community with special reference to nematodes in mangrove ecosystems. In: Soepadmo E, Rao V, Macintosh DJ (eds) Proc Asian Symp Mangrove Environments Research \& Management, Univ of Malaya - UNESCO, Kuala Lumpur, p $429-452$

McKay RJ (1992) FAO species catalogue, Vol 14, Sillaginid fishes of the world (Sillaginidae). An annotated and illustrated catalogue of the Sillago, smelt or Indo-Pacific whiting species known to date. FAO Fish Synopses 125

Nelson AL, Coull BC (1989) Selection of meiobenthic prey by juvenile spot (Pisces): an experimental study. Mar Ecol Prog Ser 53:51-57

Quinn RH (1992) Fisheries resources of the Moreton Bay region. Queensland Fishery Management Authority, Brisbane

SAS Institute (1985) SAS user's guide: statistics, Version 5 edn. SAS Institute, Cary, NC

Scholz DS, Matthews LA, Feller RJ (1991) Detecting selective digestion of meiobenthic prey by juvenile spot Leiostomus xanthurus (Pisces) using immunoassays. Mar Ecol Prog Ser 72:59-67

Service SK, Feller RJ, Coull BC, Woods RE (1992) Predation effect of three fish species and a shrimp on macrobenthos and mejobenthos in microcosms. Estuar coast Shelf Sci 34:277-293

Shaw M, Jenkins GP (1992) Spatial variation in feeding, prey distribution and food limitation of juvenile flounder Rhombosolea tapirina Gunther. J exp mar Biol Ecol 165:1-21

Smith LD, Coull BC (1987) Juvenile spot (Pisces) and grass shrimp predation on meiobenthos in muddy and sandy substrata. J exp mar Biol Ecol 105:123-136

St. John J, Jones GP, Sale PF (1989) Distribution and abundance of soft sediment meiofauna and a predatory goby in a coral reef lagoon. Coral Reefs 8:51-57

Warburton K, Blaber SJM (1992) Patterns of recruitment and resource use in a shallow-water fish assemblage in Moreton Bay, Queensland. Mar Ecol Prog Ser 90:113-126

Yetman KT (1979) The morphology of the bucco-pharyngeal filter of an estuarine fish, Leiostomus xanthurus. MSc thesis, University of South Carolina, Columbia

Manuscript first received: January 21, 1995

Revised version accepted: March 27, 1995 